\title{
Hogyan verjünk hidat az idősekhez?
}

Az idősek kapcsolati hálózatának elemzése csak mostanában kerül a kapcsolathálózat-elemzők és társadalmi tőke kutatók érdeklődésének homlokterébe. Újabb elemzések empirikusan is bizonyították azt a mindannyiunk által jól ismert jelenséget, hogy a kor előrehaladtával mind mennyiségileg, mind minőségileg átalakul a kapcsolatháló és a különböző típusú erőforrásokhoz hálózatokon keresztül megvalósuló hozzáférés. E tanulmány szerzője a kapcsolatháló beszűkülésének, átrendeződésének az idősek hálózati társadalomba való bekapcsolódását megnehezítő következményeit vizsgálja. Megállapítja, hogy az idősek az erőforrásoktól megfosztott csoportokra jellemző szubkulturális sajátosságokat mutatnak, amennyiben zárt kapcsolati és kommunikációs hálózatuk elszigeteli őket más társadalmi csoportoktól. Az elszigeteltség, a zárt hálózati struktúra egyszerre oka és következménye annak, hogy az idősek bekapcsolódása az információs társadalomba rendkívül lassú folyamatnak bizonyul.

Kulcsszavak: idősek, kapcsolatháló, erős és gyenge kötések, információs viselkedés, bizalom, IKT

\section{Szerzői információ:}

\section{Gyarmati Andrea}

szociológus jelenleg a Budapesti Corvinus Egyetemen folytat doktori tanulmányokat. Fóbb kutatási témái: a szociálpolitika és az informatika kapcsolata, közpolitikai hatáselemzések és ezek módszertana.

Így hivatkozzon erre a cikkre:

Gyarmati Andrea. „ Hogyan verjünk hidat az idősekhez?”.

Információs Társadalom IX, 4. szám (2009): 55-69. 


\section{Gyarmati Andrea}

\section{Hogyan verjünk hidat az idôsekhez?}

Az 50 év fölöttiek kommunikációs és kapcsolathálózatának néhány jellemzóje

\section{Fogalmak, elméleti összefüggések}

E tanulmányban szándékosan nem használjuk a „társadalmi tóke” rengeteg vitával terhelt fogalmát, helyette - Angelusz Róberttel egyetértve - szerencsésebbnek tartjuk az „erốforrás” kifejezést. Ebben az értelemben eróforrás számunkra az információ, a segítségnyújtás, a bizalom is, hiszen elősegíthetik és hátráltathatják is az egyéni és társadalmi cselekvést. Ezek az eróforrások a kapcsolathálón keresztül válnak elérhetốvé az egyének számára. A kapcsolathálót pedig jól jellemzik az erốs és gyenge kötések, melyeket mi is célszerúnek tartottunk elkülöníteni és felhasználni, mivel más-más a funkciójuk és különbözố módon hatnak az egyén és a csoport (a társadalom) információs-kommunikációs viselkedésre. A két fogalom közötti különbségeket foglalja össze az 1. tábla.

1. tábla

Az erös és gyenge kötések közötti különbségek

\begin{tabular}{|l|l|l|}
\hline Dimenziók & Erôs kötés & Gyenge kötés \\
\hline Definíció & szúk család, rokonok, barátok & szomszéd, ismerós \\
\hline Mennyiség & 10 alatt & sok \\
\hline Súrúség & nagy: mindenki ismer mindenkit & kicsi \\
\hline Multiplexitás (kapcsolódás) & nagy & kicsi \\
\hline Híd szerep & kis valószínúség & nagy valószínúség \\
\hline Homofília vagy heterofília & homofil (kor, iskolai végzettség) & heterofil \\
\hline Integráció & mikrotársadalmi szinten & makrotársadalmi szinten \\
\hline Nyelvi kód & korlátozott & kidolgozott \\
\hline Cselekvés & expresszív, meg akarja órizni, amije & $\begin{array}{l}\text { instrumentális, el akar érni va- } \\
\text { lamit }\end{array}$ \\
\hline Társadalmi láthatóság & bezárkózás & kinyit a világ felé \\
\hline Társadalmi státusz & alacsony & magas \\
\hline
\end{tabular}

Forrás: Angelusz Róbert közlése, 2009. május

Ezeket a hatásokat, amelyek egyrészt az egyénre, másrészt a társadalomra vonatkoznak, Granovetter klasszikus múve alapján axiómaszerúen az alábbiakban foglalhatjuk össze:

Gyenge kötések teszik lehetôvé az egyén számára a komplex szerepkészletek kialakítását, és megkövetelik hordozóiktól a szellemi rugalmasság kifejlôdését és fenntartását.

Erôs kötések használatára serkent a fizikai közelség, a szegénység és általában a hátrányos helyzet (gazdasági bizonytalanság). Ennek hatására zárt kommunikációs 
háló jön létre, amely megakadályozza bármilyen segítô program sikerét: a szegénység (eróforráshiány) önfenntartóvá válik.

„A kultúra gyakorlása feltételezi a motivációkat és fóként a kulturális témák használóival való azonosulást. Így az értékek, normák, viselkedések és tárgyak csak annyiban alkotnak egy szubkultúrát, amennyiben az egyének egy olyan közösség részének látják magukat, amelynek tagjai különleges jelentéseket tulajdonítanak ezen objektumoknak.”

Ha a központi egységek újító készségét megbéklyózzák az áthagyományozott szellemi érdekek és perspektívák, akkor az új eszméknek a hálózat peremeiról kell származniuk.

A gyenge és erôs kötések közötti munkamegosztásban a gyenge kötés a híd, amelyen keresztül az újítás átjut a társadalmi csoportok határán, míg a döntéshozást fóleg a minden egyes csoportban meglévố erốs kötések hálózata befolyásolja.

A gyenge kötések információval és olyan eszközökkel látják el az egyéneket, amelyek saját társadalmi köreikben nem állnak rendelkezésre, ám az erôs kötések nagyobb mértékben motiválják a segítségnyújtást és általában könnyebben elérhetốk.

A gyenge kötések nélküli társadalmi rendszerek széttöredezetté és inkoherenssé válnak, az új eszmék lassan fognak terjedni, a tudományos törekvések háttérbe kerülnek, és a kor, az etnikum, a földrajzi helyzet vagy más jellemzók alapján elkülönült alcsoportok nehezen fogják megtalálni a modus vivendit. (Granovetter 1991: 386)

Tanulmányunkban az adatok elemzése alapján a következô kutatási kérdéseket igyekszünk megválaszolni: Alkotnak-e az idôsek csoportot, szubkultúrát szociológiai értelemben? Szegmentálhatjuk-e óket a társas aktivitás mennyiségi és minôségi jellemzói alapján? Milyen a kommunikációs hálózatuk (zárt vagy nyitott) és ennek mi a következménye? Milyen információs viselkedést várhatunk ilyen kommunikációs helyzetben? Hogyan jut el hozzájuk bármilyen innováció (hírként és tényleges eszközként)? Képes-e a családi, erôs kötés helyettesíteni az ismerôsök által képviselt gyenge kötéseket? Értelmezhetố-e a hálózat „pereme”? A zárt kapcsolatháló vajon oka vagy következménye az IKT elutasításának?

Az 50 év feletti magyar lakosság társas kapcsolataira, infokommunikációs eszközökkel kapcsolatos attitúdjére és befektetési hajlandóságára vonatkozó kérdőíves felmérést a TÁRKI végezte el 2009 májusában és júniusában. A minta az 50 és 75 év közöttiek korosztályában nemre, korra, iskolai végzettségre, régióra és településtípusra nézve egyaránt reprezentatív, elemszáma 1003 fő.

\section{Eredmények}

\section{Az erós kötések: rokonok, barátok}

A közeli rokonok számának mediánja 10 foó. ${ }^{1}$ A megkérdezettek 28\%-ának 0-5 rokona van (a közeli rokonnal egyáltalán nem rendelkezők aránya elenyésző: mindössze hárman

1 A medián az a középsó érték, amely alatt és fölött ugyannyi elem található egy nagyság szerint rendezett sorban. Azért nem átlagokkal számoltunk, mert nagyon magas a szórás, így az átlagok félrevezetốek lennének. 
jelezték, hogy egy rokonuk sincs), 35\%-uk 5-10, 13\%-uk 11-15, 24\%-uk pedig 16 vagy több rokonnal rendelkezik. A kérdezettek megközelítőleg kétharmadának legfeljebb 10 közeli rokona van.

\section{Önnek hány közeli rokona van?}

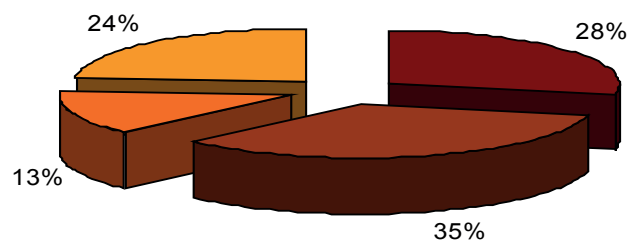

0-5 rokon $\square$ 6-10 rokon $\square 11-15$ rokon $\square 16-$

1. ábra

Rokonok sæámának kategóriák szerinti megoszlása

A barátok száma ennél jóval kevesebb, itt a medián mindössze 3 fő. Legfeljebb két barátot tudhat magáénak a kérdezettek mintegy 35\%-a (ezen belül a baráttal egyáltalán nem rendelkezók aránya 10\%), 3 barátja van további 19\%-uknak, 21\%-uk rendelkezik 4-5 baráttal, 25\%-uk pedig 6 vagy több barátot jelölt meg. A kérdezettek többsége (54\%) legfeljebb 3 közeli baráttal rendelkezik. Célcsoportunk kapcsolathálójának alapjellemzốje, hogy tagjainak átlagosan kétszer annyi rokonuk, mint barátjuk van. ${ }^{2}$

\section{Önnek hány közeli barátja van?}
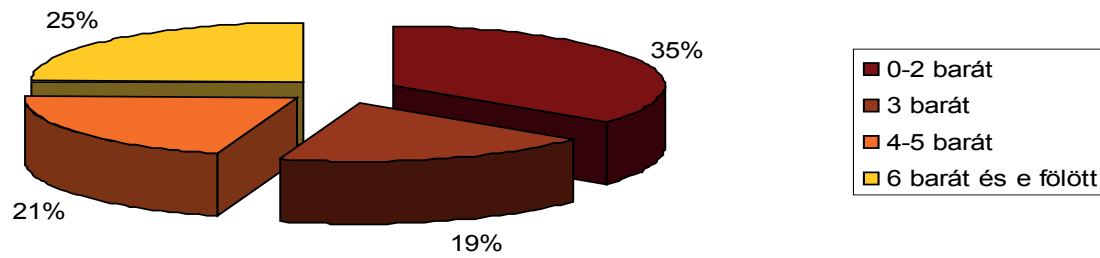

2. ábra

Barátok számának kategóriák szerinti megosะlása

\section{A kapcsolatháló múködtetése}

A kapcsolatháló fenntartása és múködtetése az erôforrásokhoz való hozzáférés egyik eszköze. A fókuszcsoportos beszélgetések tanulságai alapján megfogalmazódott bennünk az a hipotézis, hogy a kapcsolat minôsége (intimitásának foka) és a használt csatorna között feltételezhetóen korreláció van. Ezt az egyik résztvevố nagyon szemléletesen így fogalmazta meg: „Távolinak email, közelebbinek sms, még közelebb mobil, aki nagyon fontos azzal személyesen.” Ennek alapján a vizsgált kérdéssornál

2 Rokonok száma osztva a barátok számával, a medián értéke 2,3. 
azt vártuk, hogy minél közelebbi egy hozzátartozó, annál jellemzóbb lesz a személyes kontaktus. A válaszok tanúsága szerint a megkérdezettek $90 \%$-a találkozott személyesen családtagjával, rokonával az elmúlt héten, míg barátjával vagy ismerôsével 82\%-uk, általa addig ismeretlen emberrel azonban már csak 35\%-uk került személyes kapcsolatba. Telefonon a családtagokkal, rokonokkal 86\%-uk, míg barátokkal vagy ismerôsökkel már csak 65\%-uk beszélt, korábban ismeretlenekkel pedig mindössze 19\%-uk került így kapcsolatba. Az internetes kapcsolattartás jóval kevésbé elterjedt: családtagjaival és barátaival 15-15\%-uk érintkezett így, idegenek esetében ez az arány mindössze 4\%. Ezek az eredmények ast mutatják, hogy a intimitás foka nem magyaráz:a a használt csatornát: a közeli hozzátartozókkal a leggyakoribb a kontaktus minden csatornán, a távoli ismerósökkel pedig minden csatornán ritka. Ha a kommunikációs csatornákat vetjuik össze, ssintén ast találjuk, hogy nincs funkcionális elkïlönülés: a kapcsolat intimitásának fokától függetlenül a leggyakoribb a személyes kontaktus, ennél ritkább a telefonos és még ritkább a: interneten keresztuili kommunikáció.

\section{A kérdezettek hány százaléka beszélt múlt héten családtaggal, baráttal, ismeretlennel személyesn, telefonon, interneten}

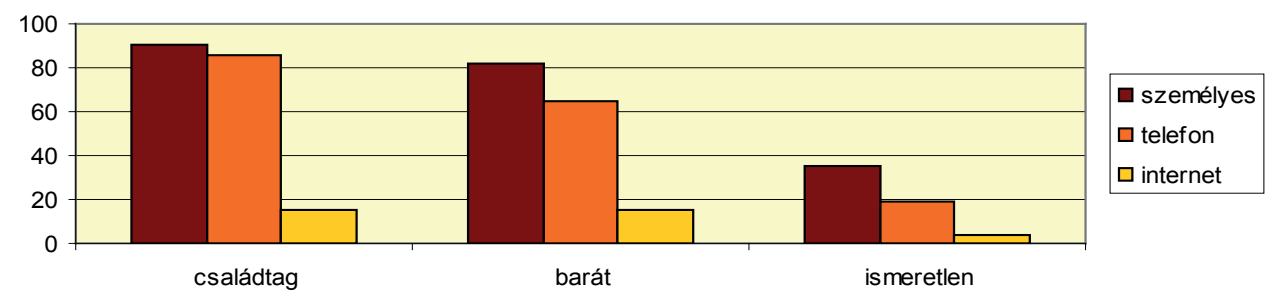

3. ábra

Kommunikációs csatornák használata az intimitás foka szerint

\section{Kapcsolattartás, társas tevékenységek}

A következókben különbözố társas tevékenységek végzésének gyakoriságát elemezzük. Az adatok azt mutatják, hogy a végæett társas tevékenység gyakoriságát legerósebben a tevékenység kö̈ga:daságtani értelemben vett költségessége határoz:a meg. Más szóval: minél többet kell utazni, pénzt és idoót ráfordítani, intellektuálisan felkészülni valamely tevékenységre, annál ritkábban végzik az idôsek. A leggyakoribb társas tevékenységük egyértelmúen a szomszédokkal való beszélgetés, ezt a kérdezettek több mint $80 \%$-a néhány naponta megteszi. A második leggyakoribb a rokonokkal való találkozás (56\%uk esetében néhány napja történt, hogy rokona meglátogatta), de ettól nem sokkal marad el a barátokkal való találkozás sem. A helyváltoztatással, utazással járó tevékenységek jóval ritkábbak, ezek közül a hivatalos ügyek intézése a leggyakoribb (a kérdezettek 25\%-a foglalkozott ezzel a felmérést megelőzố napokban), itt nyilván elég erôs motiváló erố a kényszer. A másik oldalon a ritkán végzett tevékenységek közé tartozik a színház-, múzeum- és könyvtár-látogatás, az önkéntes munka és a családtagoktól (gyerekektól, unokáktól) érkezô elektronikus üzenetek fogadása - ezek mind magas, elsốsorban szellemi aktivitási szintet feltételeznek. 
Akad egy tevékenység, amely a költségelemzés szempontjából „kilóg a sorból”, nevezetesen az SMS-küldés. SMS-t küldeni olcsó és gyors módja a kommunikációnak, ugyanakkor vegyük figyelembe, hogy a legtöbb készülék nem idôsbarát (kicsi gombok, kisméretú kijelzó), s így nehezen kezelhetô az idősek számára. Másrészt feltételezhetô egy bonyolultabb összefüggés is az idôsek SMS-t kerülő kommunikációs viselkedése mögött. Ha belegondolunk, hogy mi magunk mikor küldünk SMS-t (például a másik fél nem tud telefonon beszélni, de fontos lenne egy információt eljuttatni hozzá), akkor nem nehéz rájönni, hogy ez a sürgôs információküldés az idősek mindennapjainak nem része, nincs rá szükségük. Ha valamit nem tudnak elmondani, mert a másik nem veszi fel a telefont, ráér késóbb is. Más az idóhöz való viszony idős korban, feltehetóleg ez nyilvánul meg az eszközhasználatban is.

\section{Mikor végezte legutoljára az alábbi tevékenységet?}

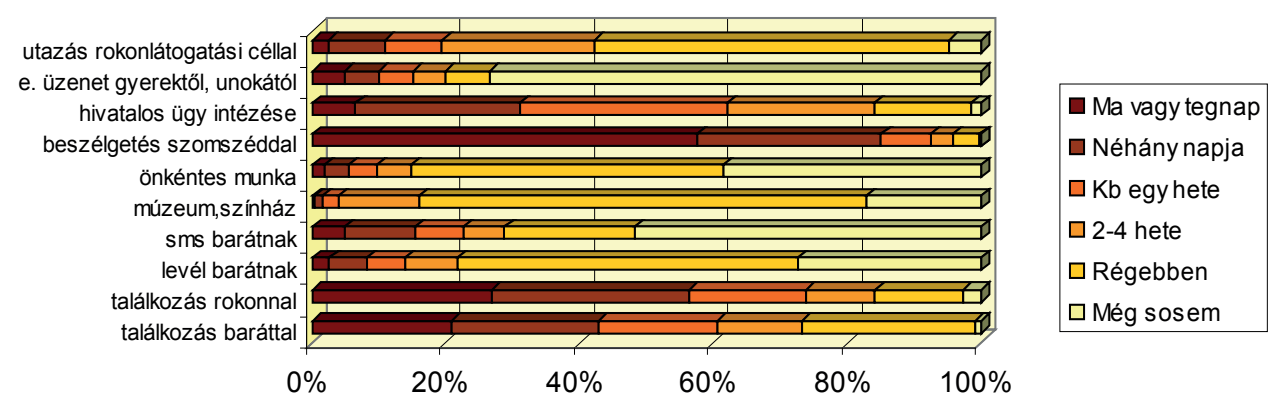

4. ábra

Társas aktivitás idóbeli gyakoriság szerint

Az adatok könnyebb kezelhetősége érdekében a társas aktivitásra vonatkozó változókat aggregálva létrehoztunk 3 klasztert (2. tábla). A tevékenységek végzésének gyakorisága szerint megkülönböztettük a magas szintû́ társas aktivitással jellemezhetô személyeket (akik gyakran végzik a felsorolt tevékenységeket), a közepesen aktívakat és a passzívakat. A klaszterek jól mutatják, hogy a megkérdezettek közel 70\%-át a társas tevékenységekben passzíak alkotják.

2. tábla

Társas aktivitás klaszterek

\begin{tabular}{|l|c|c|c|}
\hline \multicolumn{1}{|c|}{ Klaszterek } & Átlag & $N$ & $\%$ \\
\hline Magas társas aktivitás & 2,7 & 182 & 18,9 \\
\hline $\begin{array}{l}\text { Közepes szintú társas aktivi- } \\
\text { tás }\end{array}$ & 3,5 & 117 & 12,2 \\
\hline Társas passzivitás & 4,0 & 659 & 68,8 \\
\hline
\end{tabular}

Megjegyzés: minél alacsonyabb az átlag, annál gyakoribb az aktivitás.

A társas passzivitás aránya a vizsgált korcsoportban tehát rendkívül magas. Összehasonlításként: a szellemileg passzívak aránya csupán 31,6\% (vö. Gyarmati Andrea: Az aktivitás szerepe az IKT időskori felhasználásában). Mint ahogy azt az idézett tanulmányban bemutattuk, a fizikai, a szellemi és a társas aktivitás statisztikailag összefügg 
egymással és erôsen hat az IKT elfogadottságára is. Mindezek alapján ajánlásként megfogalmazható, , hogy a célok meghatározása során stratégiai szinten is érdemes lenne az idôsek társas aktivitásának növelését prioritásként kezelni. Az idôsek társas aktivitásának növelése az áttételeken keresztül az egészségügytôl a foglalkoztatáspolitikán át a civil részvételig minden közpolitikai területre rendkívül pozitív hatással lehet, és nem elhanyagolható mértékben javítja az idôsek életminóségét is.

\section{Az információszerzés csatornái: a család elsóbbsége}

A továbbiakban arra keressük a választ, hogy az idôsek hogyan használják információs csatornaként a kapcsolataikat. Ahogy az 5. ábrából leolvasható, a célcsoport tagjai elsốsorban a tévéból, családtagjaiktól, a rádióból és az újságokból tájékozódnak. A gyenge kötések (internet, ${ }^{3}$ postás, szakemberek, ismerősök) jelentősége az információhoz jutásban általában véve elhanyagolható: soha nem tájékozódik szakembertől vagy ismerőstől a kérdezettek $61 \%$-a, míg a postás esetében ez a 45\%-ukról, az internet tekintetében $75 \%$-ukról mondható el. Nem nehéz belátni, hogy az erős személyes kapcsolatokon keresztül történő, valamint az egyirányú médiának a szerkesztők és müsorkészítők által szürt információiból való tájékozódás zárt láncú, belterjes kommunikációt eredményez. $A z$ idösek kommunikációs hálóit jogosan nevezhetjük tehát a granovetteri értelmében zártnak, az így létrejövö kommunikációs gyakorlatot pedig intenzívnek, introvertáltnak.

\section{Milyen gyakran tájékozódik az alábbi csatornákon keresztül?}

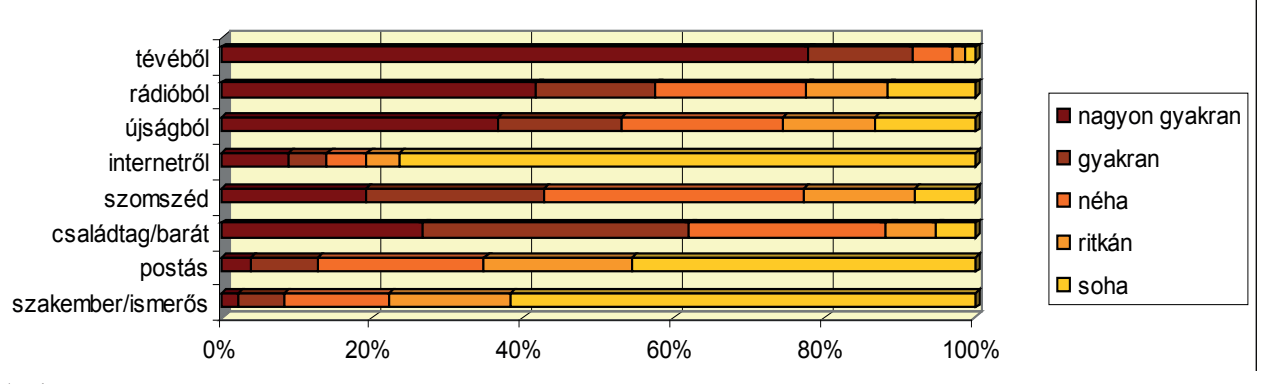

5. ábra

A általános tájékozódás csatornái

A kommunikációs háló egyszerúbb kezelhetôsége érdekében két „fókomponensbe” aggregáltuk a változók értékeit. Azt vártuk, hogy ilyen módon sikerül majd elkülönítenünk egymástól az „inkább zárt” és az „,inkább nyílt” információs láncokkal jellemezhetố személyeket, de a létrejött fókomponensek nem igazolták várakozásainkat. Az elsố fókomponensbe azokat sikerült tömörítenünk, akik elsốsorban személyes kapcsolataikat (a családot, barátaikat és ismerôseiket) veszik igénybe tájékozódáshoz, a másikba pedig azokat, akik a médiára (ezen belül is a rádióra és az újságokra) támaszkodnak. A fókom-

3 Az internet - szemben a többi médiával - gyenge kötésként funkcionál, nyílt és sokrétú kommunikációs gyakorlatot tesz lehetôvé, alacsony integrációs szint mellett. 
ponenseket alkotó változók közül két változót kihagytunk a végsố struktúrából: a televíziót és az internetet. (Az elóbbit azért, mert televíziót mindenki néz, az utóbbit pedig azért, mert az internetet nagyon kevesen használják.) A személyes kapcsolatokat mint tájékozódási csatornát tömörítô fókomponensben a megmaradt információ 52\%-ot tett ki, míg a médiát tömörítố fókomponens 63\%-ot ôrzött meg. A személyes kapcsolatokon, illetve a médián keresztül történó tájékozódást a magyarázó hierarchikus ANOVA modellekbe bevonva azt találtuk, hogy a hagyományos magyarázó változók (nem, kor, iskolai végzettség, településtípus, együtt élók száma) csốdöt mondtak, ezzel szemben a szellemi aktivitást mérố változónk szignifikáns összefüggést mutatott. A szellemileg aktívak nagyjából kétszer olyan gyakran használják a médiát tájékozódásra, mint a személyes kapcsolatokat. Ugyanez az arány jellemzố a közepesen aktívnak nevezett csoportra is, azzal a különbséggel, hogy ók nagyobb mértékben használják mind a médiát, mind a személyes kapcsolatokat tájékozódásra, mint a szellemileg aktívak (azaz az átlagok magasabbak, de a média használata kétszer gyakoribb, mint a személyes kapcsolatoké). Ezzel szemben a legnagyobb csoportot alkotó szellemileg passzívak szinte egyáltalán nem használják tájékozódásra a médiát (ne felejtsük el: a rádióról és a sajtóról van szó), de a személyes tájékozódás is körükben a legalacsonyabb mértékú.

3. tábla

Tájékozódási csatornák és szellemi aktivitás

\begin{tabular}{|l|c|c|c|}
\hline \multicolumn{1}{|c|}{ Aktivitás klaszterek } & $\begin{array}{c}\text { Személyes tájékozódás } \\
\text { Fökomponens škór }\end{array}$ & $\begin{array}{c}\text { Média (újság, rádió) } \\
\text { Fókomponens szkór }\end{array}$ & $N$ \\
\hline Szellemileg aktív & 0,14 & 0,28 & 277 \\
\hline Közepesen aktív & 0,26 & 0,40 & 315 \\
\hline Szellemileg passzív & $-0,45$ & $-0,75$ & 391 \\
\hline
\end{tabular}

Ez az eredmény azért meglepó, mert logikusnak túnt egy olyan feltételezés, hogy minél aktívabb valaki szellemileg, annál gyakrabban tájékozódik a különbözó információs csatornákon keresztül. Ezzel szemben az adatok azt mutatták, hogy a leginkább kiegyensúlyozott kommunikációs gyakorlattal az általunk közepesen aktívnak nevezett csoport bizonyult. Az ố köztes helyzetükból logikailag következne egyfajta híd vagy összekötố szerep a két másik csoport felé, azonban ennek az alátámasztásához további kutatásokra lenne szükség.

\section{Segítségnyújtási háló}

A segítségnyújtás, a szívességek és elvárások esetében ugyanolyan, a cselekvést elôsegítô erôforrásról, eloónyrốl van szó, mint a fent elemzett információ esetében. A segítségnyújtási hálóról három változó adatai alapján alkothatunk képet. Elôször is rákérdeztünk arra, hogy mindennapi, szokásos tevékenységek végzésében kitól várhatnak a kérdezettek segítséget, és ezt szokták-e viszonozni, majd ezt kiterjesztettük extrém helyzetekre is.

Az elsố kérdéssorban tehát arra voltunk kíváncsiak, hogy az általunk felsorolt, a mindennapi életben fontosnak tartott tevékenységekben a megkérdezett idôs emberek kitốl, milyen szerepet betöltố személytốl remélhetnek segítséget. Általában minden tevékenység esetében a család szerepe a legfontosabb, ezen belül is kiemelkedő 
a mindennapi tevékenységekben való segítség elvárása (90\%). Inkább csak azokban a tevékenységekben esik vissza - de itt is csak kis mértékben - a család szerepe, ahol szaktudásra van szükség (múszaki cikkek beállítása, kisebb javítások a háztartásban). A második leggyakoribb segítố funkciót a barátok, szomszédok töltik be: tólük a kérdezettek leginkább a bevásárlásban és receptek kiváltásában várnak segítséget. A mindennapi tevékenységekben való segítség, mint láttuk, a család felségterülete. Ismerôsöktốl átlagosan a kérdezettek $6 \%$-a vár segítséget, fóként szaktudást igénylő probléma esetében (javítások, készülékek beállítása), de ugyanez jellemzó a szakemberektól elvárt segítségre is (az ismerôsök fóként a szakemberek közül kerülnek ki). A postásnak és az orvosnak sincs kitüntetett szerepe a segítségnyújtási hálóban: tólük, illetve a nem pontosított „valaki mástól” elenyészố számban és mértékben várnak segítséget a kérdezettek. A segítségnyújtási hálóban is szinte kizárólagos az erós kötések szerepe.

4. tábla

Ha sæïksége lenne rá, kitól kaphatna segítséget (\%)

\begin{tabular}{|l|c|c|c|c|c|c|}
\hline \multicolumn{1}{|c|}{ tevékenység } & családtól & $\begin{array}{c}\text { barát/ } \\
\text { szomszéd }\end{array}$ & ismerös & $\begin{array}{c}\text { postás, } \\
\text { orvos }\end{array}$ & $\begin{array}{c}\text { más sæak- } \\
\text { ember }\end{array}$ & $\begin{array}{c}\text { valaki } \\
\text { mástól }\end{array}$ \\
\hline bevásárlás, receptek & 87,9 & 31,4 & 7,9 & 0,4 & 1,1 & 0,8 \\
\hline csekkek befizetése & 86,5 & 26,9 & 5,4 & 1,6 & 0,8 & 0,7 \\
\hline fózzés & 86,4 & 18,0 & 3,1 & 0 & 1,6 & 1,8 \\
\hline hivatalos ügyek intézése & 88,5 & 20,2 & 5,9 & 0,7 & 1,9 & 0,7 \\
\hline mindennapi tevékenységek & 90,0 & 13,0 & 2,2 & 0,2 & 2,4 & 0,7 \\
\hline utazás,közlekedés & 87,6 & 24,9 & 6,7 & 0,1 & 1,6 & 1,0 \\
\hline múszaki cikk beállítása & 81,4 & 25,1 & 10,4 & 0,3 & 16,6 & 1,3 \\
\hline javítások a háztartásban & 76,7 & 25,4 & 11,8 & 0,2 & 23,6 & 1,2 \\
\hline magánéleti probléma & 83,0 & 23,6 & 4,0 & 0,9 & 4,0 & 1,8 \\
\hline átlag & 85,3 & 23,2 & 6,4 & 0,5 & 6,0 & 1,1 \\
\hline
\end{tabular}

Megjegyzés: A táblázat az igen válaszok megoszlását mutatja minden egyes szerepnél. Több válasz is megjelölhetố volt.

A segítségnyújtás viszonzásáról annyit állapíthatunk meg, hogy a szomszédoknak, családnak való segítés a leggyakoribb tevékenyég a vizsgált korosztály aktivitási mintázatában: 79\%-uk segít rendszeresen a szúkebb környezetének (vö. 2. ábra). A családok, szomszédok egymásra utaltsága, szolidaritása tehát nagyon erốs, aะ idốs emberek közvetlen környezetében magas az integráció foka.

Az különbözố, való másokra való támaszkodás a fenti, A mindennapi élethelyzetekben jellemzố fenti képet némileg árnyalja, hogy extrémebb szituációkban kihez fordulnak a megkérdezettek. Erre a következó kérdéseink vonatkoztak:

Ha munkát keresne, kitól várhatna leginkább segítséget?

Ha anyagi nehézségek esetén kisebb áthidaló kölcsönre lenne szüksége, kitôl várhatna leginkább segítséget?

Ha nehéz élethelyzetben meg akarja osztani érzéseit valakivel, kitól várhatna leginkább segítséget?

Ha otthonától távol elromlik az autója vagy utazás során nem tud hazajutni, kitôl várhatna leginkább segítséget? 
Ha beázás miatt néhány napig máshol kényszerül aludni, kitól várhatna leginkább segítséget?

Ha egészségügyi probléma esetén tanácsot kérne, orvost ajánlani, kitól várhatna leginkább segítséget?

Ha vitás jogi ügye van, ügyvédre, jogi tanácsra van szüksége, kitốl várhatna leginkább segítséget?

Átlagosan a legtöbb helyzetben a kérdezettek közül a legtöbben a családra támaszkodhatnak (70\%), ez után következnek a barátok (átlag: 10\%), a harmadik leggyakoribb válasz: „senkitól” (7\%), a negyedik az „egyéb” kategória (6\%) majd a sor végén következik holtversenyben a „családi ismerôs” és a „(volt) kolléga” (3-3\%). Az átlagtól való eltéréseket nézve kiderül, hogy a családtagok szerepe kiemelkedôen fontos a „beázás esetén megszállni” szituációban (83\%) és az érzelmi támogatásban (81\%), míg jóval kevésbé fontos a munkakeresésben (45\%) és a jogi tanácskérésben (59\%). A barátokat a legtöbben az érzelmi támogatásnál (12\%) és az utazás során adódó problémák szituációjában (12\%) jelölték meg elsôdleges segítségnyújtóként. Jelenlegi vagy korábbi kollégáktól fóként munkakeresésben várnak segítséget (16\%). Családi ismerôsöktól a kérdezettek 7\%-a vár jogi tanácsadást, s az „egyéb” kategóriába esố személyektól szintén fóként a jogi kérdésekben várnak segítséget (16\%). A „senkitól” opciót a munkakeresés esetében választották sokan: a kérdezettek nagyjából ötöde (19\%) adta ezt a választ. Ez az utóbbi adat ráerósít a granovetteri elmélet egyik elemére: a munkakeresést is magában foglaló társadalmi mobilitásban elsốdleges a gyenge kötések (linking és bridging típusú) kötések szerepe, amelyek - mint láttuk - az idôseknél gyakorlatilag hiányoznak.

\section{Különböző élethelyzetekben kitől számíthat segítségre?}

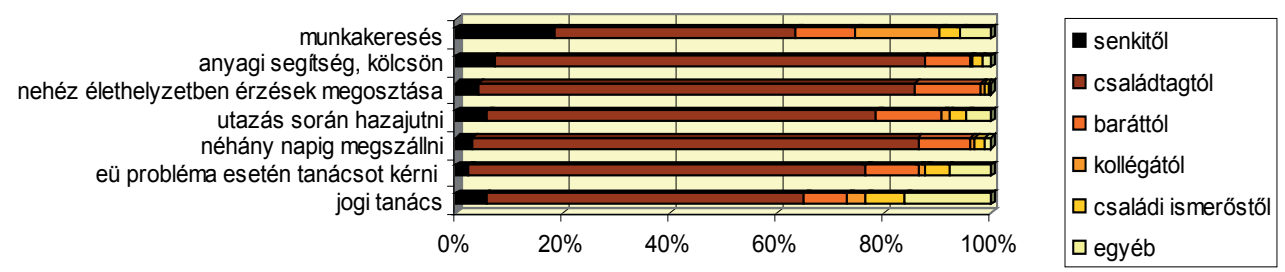

6. ábra

Különbözó élethelyzetekben várt segitség

\section{Bizalom és szégyen}

A bizalom szintén a társas viszonyainkban gyökerezó eróforrás: kutatások (Putnam 2000, Fukuyama 1995) bizonyítják, hogy minél magasabb a bizalom szintje egy társadalomban, annál nagyobb a jólét, fejlettebb a gazdaság, az emberek pszichésen egészségesebbek, magasabb a termékenység stb. (Szántó 2006). Ezért, és mert feltevésünk szerint az internethasználatnak is az egyik kulcstényezójéról van szó, a bizalom szá- 
munkra is kitüntetett jelentôséggel bírt. Az adatok azt mutatják, hogy az idôsek az elektronikus ügyintézésben általában nem bíznak, és sokan gondolják úgy, hogy az emberek életében történô események egyre kevésbé kontrollálhatók. A nem használathoz kapcsolódó szégyen a többségre nem jellemzố.

\section{Mennyire ért egyet a következő kijelentésekkel?}

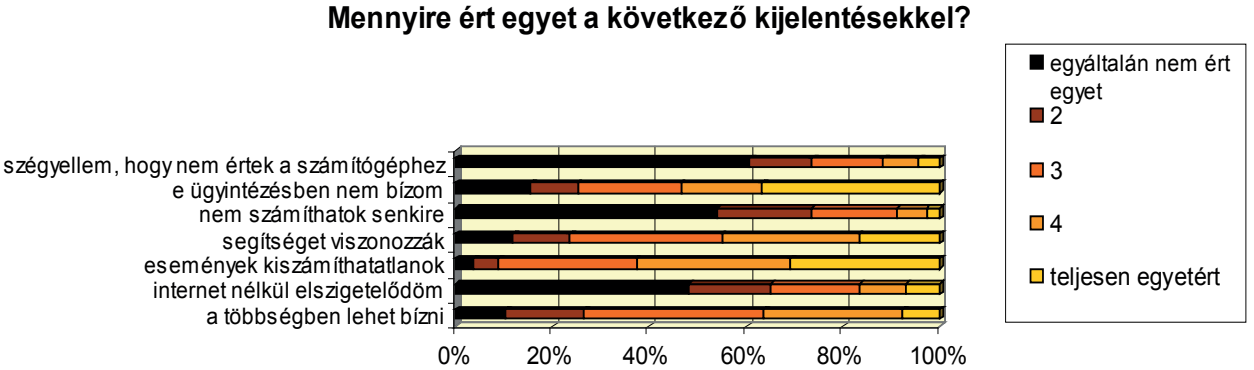

7. ábra

Bizalom, szégyen, IKT

Az itt felsorolt változókból a korrelációk alapján két „fókomponenst” sikerült létrehozni. Az egyiket biæalom-faktornak neveztük, és a következố kijelentésekkel való egyetértést soroltuk ide: „az emberek többségében meg lehet bízni”, „, ha segítek valakinek, viszonzásra számíthatok”, és „ha valamilyen gondom adódik, számíthatok másokra” (ez utóbbi a „nem számíthatok senkire” válaszlehetốség inverze). Az aggregált változó által megórzött információtartalom 39\%, ami még elfogadható, a faktor szórok mediánja +0,08. A másik fókomponenst šégyen-faktornak neveztük el és az alábbi kijelentéseket mint változókat vontuk be ide: „szégyellem, hogy nem értek a számítógéphez, internethez”; „azzal, hogy nem használom az IKT eszközöket, elszigetelődöm”, és „a közeli hozzátartozók már mind használják az internetet, számítógépet”. Itt a megôrzött információtartalom már 48\%.

A szégyen-faktor és a bizalom-faktor között nincs statisztikai összefüggés, az egyik nem magyarázza a másikat, azaz pl. nem igaz az, hogy minél magasabb a bizalom szintje, annál alacsonyabb a szégyen és fordítva. Magyarázó modellbe bevonva a bizalom faktort azt találtuk, hogy a bizalom magas szintjét három változó magyarázza szignifikánsan: a rokonok száma (a bizalom-faktor értéke 6 rokon fölött lesz pozitív), a barátok száma (itt pedig a pozitív küszöb 5 fó), és a magányosság mértéke (minél kevésbé érzi magát valaki magányosnak, annál magasabb nála a bizalom szintje). Az ANOVA modell szignifikáns, bár a megmagyarázott hányad kevés. A béták alapján a magányosság érzése bírt a legerôsebb magyarázó erôvel $(0,13)$, a legkisebbel pedig a rokonok száma $(0,1)$, de nem jelentốs a különbség. A három magyarázó változó között - rendkívül meglepó módon: sem kettesével, sem összesen - nincs szignifikáns összefüggés, azaz mind a rokonok száma, mind a barátok száma, mind pedig a magányosság szintje önálló, a többi változótól független magyarázó erốvel bír a bizalom szintjére. A szégyen-faktort ugyanezzel az eljárással elemezve azt találtuk, hogy az értéke általában alacsony (faktor szkór mediánja -0,23), de annál magasabb, minél magányosabbnak érzi magát a kérdezett, illetve minél magasabb az iskolai végzettsége (csupán ennek a két változónak volt szignifikáns magyarázó ereje). 
A magas fokú bizalom és a csekély szégyenéræet két dologra utal: egyrészt a közvetlen környezetbe való magas szintú integrálódásra, beágyazottságra, másrészt arra, hogy ennek a közvetlen környezetnek egyáltalán nem tartozik a csoportnormái közé aะ IKT-hasะnálat elvárása (ez utóbbi as életkortól független, a magas iskolai végæettségüek csoportjában érzékelhetó elvárás).

\section{IKT (ellátottság, használat, attitúd), beruházási hajlandóság}

\section{Tájékozódás}

Az internet előnyeirốl és hátrányairól különbözố csatornákon keresztül tájékozódnak a megkérdezettek. Az elónyeiról nagyrészt a családon keresztül (45\%-ban említették a kérdezettek a családot elsố helyen), míg a káros hatásairól a televízión, rádión keresztül kapnak információt (34\%). Ez a tájékozódási stratégia eltér a fent elemzett általános informálódási stratégiától, ahol egyértelmúen a médiáé volt a vezetô szerep. Mint korábban is jeleztük, a magas fokú integráció, az erós kötések és a sárt kommunikációs hálók természetiiknél fogva szúrố szerepet töltenek be az internetröl, illetve bármilyen technikai és kulturális innovációról való tájékozódásban. Nem segítik elö az innováció terjedését, csupán segítik egy már meghozott döntés (pl. az egy új technikai eszköz kipróbálása) kivitelezését. Az offline médiával kapcsolatban hasonló következtetést vonhatunk le. A tévének és a rádiónak ugyanúgy szúrố szerepe van az internettel kapcsolatban, mint a családnak, csak éppen negatív irányban (emiatt tapasztaltuk azt a fókuszcsoportok során is, hogy az idôsek kizárólag a televízióból és a rádióból értesültek az internet káros hatásairól).

\section{IKT esжközök a háztartásban}

A jelenlegi eszköz-ellátottságról azt mondhatjuk, hogy televízió minden háztartásban van, mobiltelefonnal a kérdezettek kétharmada rendelkezik, számítógépe és internet-hozzáférése azonban már csak minden negyedik személynek van közülük. Ez utóbbiak 12\%-a mobil internetet használ. Magas a GPS-szel rendelkezók aránya: 8\%.

\section{Rendelkeznek-e az alábbi eszközökkel?, igen, \%}

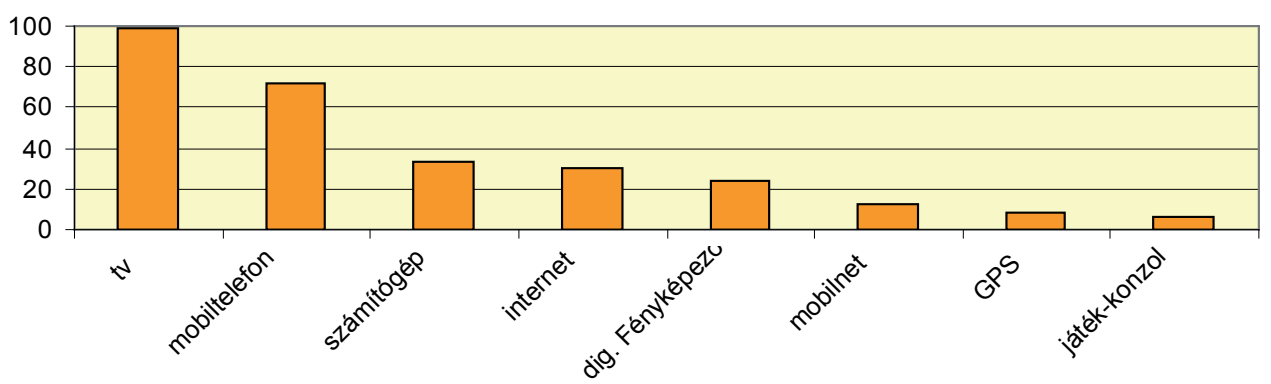

8. ábra

IKT eszközökkel való ellátottság 


\section{Azeszközök havi dija}

Mobiltelefonra a kérdezettek 25\%-a nem költ (nekik nincs is mobiltelefonjuk, tehát nem igaz az a hipotézis, hogy valaki más fizetné a mobiltelefon-számlát az idôsek helyett), tv-elófizetése 23\%-nak nincs (bár TV-je 98\%-nak van), vezetékes telefonra 35\%, internet-elófizetésre pedig $70 \%$ nem költ. Akinek van mobilja, az átlagosan havonta 3800 forintot költ rá, a televízió-elófizetés díja körükben átlagosan 3600 forint. A vezetékes telefon átlagosan 4400 forintba kerül havonta, az internet-elófizetéssel rendelkezók (a válaszadók kb. 30\%-a) pedig átlagosan 4800 forintot költenek az eszköz fenntartására.

\section{Beruhá:ási hajlandóság: „a családomat támogatnám”}

Az adatok alapján nem beszélhetünk az idôsek IKT eszközökbe való beruházási hajlandóságáról. A kérdezettek döntố többsége (82\%) semmilyen eszközét nem kívánja egy éven belül lecserélni. A fennmaradó $17 \%$-uk nagy része fóként a mobiltelefonját (74\%), illetve a televízióját (68\%) cserélné le szívesen. Mindössze 20-30 fő cserélné újra a számítógépét és az internet-elófizetését. Az ezekre az eszközökre szánt összegek mediánja 35 ezer Ft, vagyis a beruházást tervezók fele költene ez alatti, fele pedig e fölötti összeget. Semmiképp sem állíthatjuk azonban, hogy a beruházási hajlandóság pénz kérdése lenne, mivel még az sem ösztönözné az 50 év felettieket az IKT eszközök beszerzésére, ha váratlanul nagyobb összeghez jutnának. Ebben az esetben a kérdezettek 3\%-a költene csupán tartós fogyasztási cikkekre. A többség a családját támogatná (43\%), de sokan (összesen 20\%) vennének ingatlant is vagy bôvítenék a meglevó ingatlanjukat, ami közvetve szintén a család támogatásának számít. Saját magukra kevesen költenének a korosztály tagjai közül (utazás, egészség: 18\%). 13\%-uk tenné félre az összeget, 3\%-uk pedig egyéb, általunk nem említett célra költené. A vizsgált korcsoportra, úgy túnik, egyáltalán nem jellemzóek a mindennapi megélhetési gondok. Az újabb jövedelemvizsgálatok is azt bizonyítják, hogy ebben a korcsoportban a legkisebb mértékú az egyenlótlenség és a szegénység, ${ }^{4} s$ erre a jelenlegi vizsgálat is ráerôsít: mindössze 3 fő $(0,3 \%)$ nyilatkozott úgy, hogy a váratlanul kapott nagyobb összeget élelmiszerekre költené.

\section{Ha váratlanul nagyobb összeghet jutna, mire költené?}

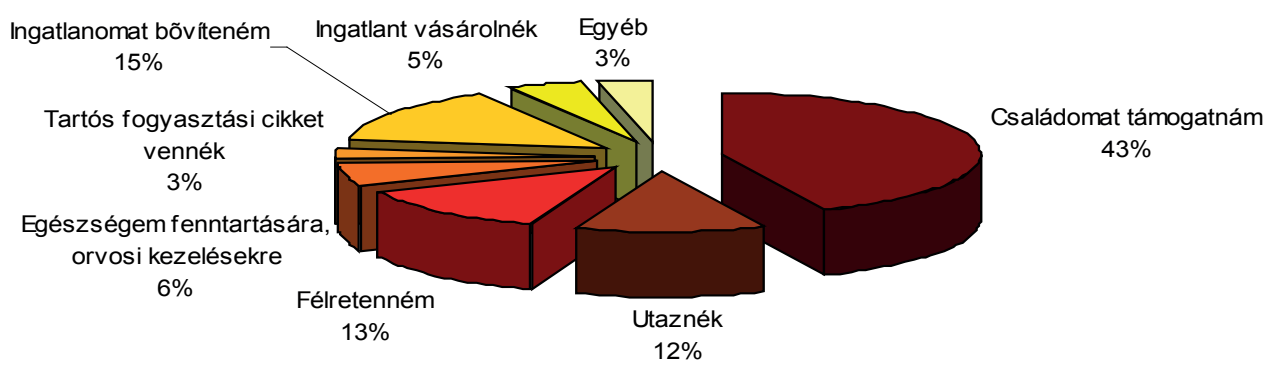

9. ábra

Egy nagyobb összeg elköltésének célja

4 Itt a Társadalmi Riport 2006-os kötetének (szerk. Kolosi Tamás, Tóth István György és Vukovich György) két tanulmányára érdemes hivatkozni: Tóth István György: „Jövedelemeloszlás 1987 és 2005 között”, és Gábos András - Szívós Péter: „A gyermekszegénység és néhány jellemzôje Magyarországon.” 
Hogy miért tartják a legfóbb, leginkább preferált pénzköltési módnak a család támogatását, annak feltehetôleg a korosztály egészére érvényes szocializációs okai vannak, ugyanakkor ebból (és a korábbiakban a zárt kommunikációs hálózatokról elmondottakból) levonhatunk bizonyos következtetéseket. A korosztály bármilyen beruházást (IKT eszközökbe vagy más, önmaguk számára hasznos célra) csak a család szúrôjén, jóváhagyásán keresztül hajlamos megvalósítani, a család tudja csak legitimálni, normává tenni az idős emberek számára bármilyen eszköz birtoklását vagy új célok kitúzését, ideértve az IKT eszközök beszerzését és ezek használatát is. Ajánlásként

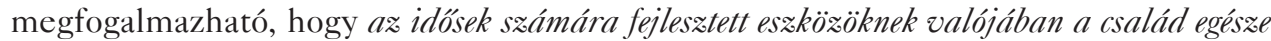
számára kell készülniük; maguk az idósek egyelóre nem kezelhetók a családjukból kiszakitott, önálló IKT-beruházási döntéshozókként.

Internet? - Nekem még ingyen se kellene...

Külön kiemelve a számítógépet és internetet, a fentiek ismeretében már nem meglepóek a következó adatok: A kérdezettek 48\%-ának ingyen sem kellenének ezek az eszközök. A válaszadók 32\%-a nem látja értelmét az internetezésnek, míg azoknak az aránya, akik „valószínúleg”, illetve „gondolkodás nélkül” befektetnének ezekbe, mindössze 14, illetve 6\%. Ez annyit jelent, hogy az idôsek 80\%-a mereven elzárkózik tólük.

\section{Ha megtehetné, vásárolna-e otthonába számítógépet, internetet?}

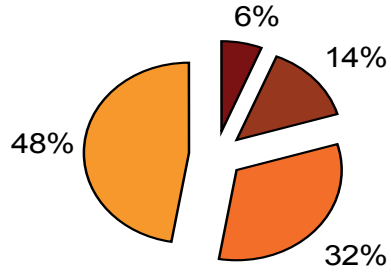

10. ábra

Venne-e számítógépet, internetet otthonra?

$\square$ Igen, gondolkodás nélkül
$\square$ Valószínûleg igen
$\square$ Valószínûleg nem, nem látom
hasznát, értelmét
$\square$ Nekem még ingyen sem kellene
otthonra számítógép, internet

Vagy ha mégis: az unoka miatt!

A motivációk felól közelítve az internet-előfizetéshez, a legtöbben a család kedvéért (az unokákkal, rokonokkal való kommunikáció elősegítésére), illetve tájékozódás, a hírekhez való hozzájutás érdekében vennének IKT eszközöket, a legkevésbé pedig a szórakozás, a hivatalos ügyintézés és a munka motiválná óket ilyen beruházásra. Érdekes megfigyelni, hogy az unokák és a tájékozódási igények egyforma súllyal esnek latba: pontosan ugyanannyian köttetnék be az internetet az elóbbi, mint az utóbbi motiváció alapján. Talán nem túnik túlzásnak egyfajta hír-függésról beszélni a korosztály esetében, ami további elemzést igényelne (milyen híreket hallgatnak vagy olvasnak az idôsek és miért, mire használják fel a híreket stb.): ez a fajta hír-függés feltételezésünk szerint nem azonos az információ iránti szükséglettel. 


\section{Milyen céllal venne otthonra Internetet? (\%)}

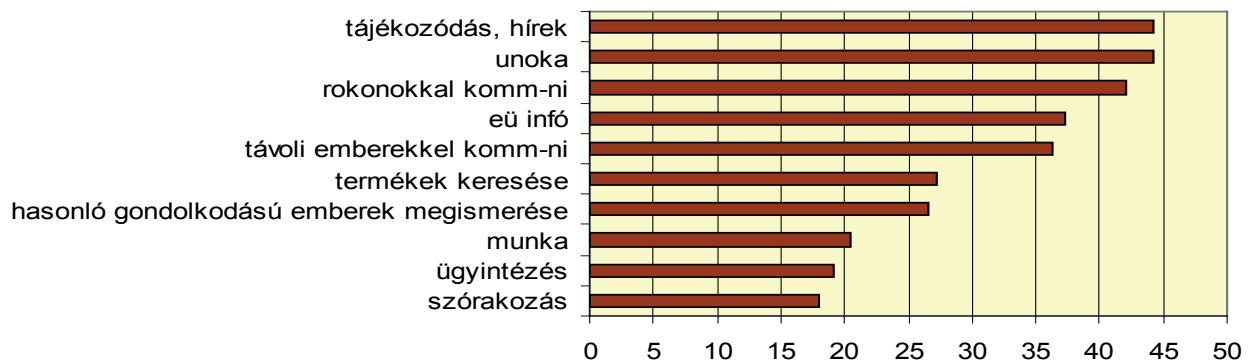

11. ábra

Az internet-hozzáférés meglétére motiváló tényezók

\section{Következtetések}

A bevezetésként feltett kérdésekre az ismertetett adatok fényében összegzésként a következố válaszokat adhatjuk:

A magyarországi idôsekról elmondhatjuk, hogy az eróforrásoktól megfosztott csoportokra jellemzó szubkulturális sajátosságokat mutatnak. Erre utal a zárt kapcsolatháló, a csoporton belüli homofília, a belterjes kommunikáció és az önmagukról alkotott lehangoló kép, mely a fókuszcsoportos beszélgetések során jött elő. Mindebból egyenesen következik, hogy társadalmi cselekvéseik erósen korlátozottak.

A homofíliát az aktivitás különbözó fajtái képesek csak megtörni: különösen fontos a szellemi és a társas aktivitás mint csoportképzó változó és mint közpolitikai beavatkozási pont.

Az életminôségüket javító beavatkozások mérlegelésekor $a$ idóseket nem sæabad és nem is érdemes a szúkebb környezetüktól, családjuktól elkülönítve kezelni.

A család kapcsán fontos lenne képet kapnunk a családon belüli hierarchiáról, mivel az információ zárt közösségben fentról lefelé terjed, azaz jó lenne tudni, hogy a családokon belül az idôsek milyen hatalmi, információs pozíciót foglalnak el.

Kevés gyenge kötésük miatt az idôsek csak nehezen vagy egyáltalán nem jutnak hozzá az új információkhoz, s ezek között különösen az olyan innovációkról való tájékozódáshoz, amelyek megnövelhetnék a gyenge kötések számát, és ez ördögi kört eredményez. A kapcsolathálót kinyitni csak az IKT eszközök segítségével lehet, de az az ezekre vonatkozó információk csak nyitottabb kapcsolati és kommunikációs hálón keresztül tudnának eljutni hozzájuk.

A peremhelyzet nehezen értelmezhetó: nem tudjuk, kit kellene keresnünk ilyen pozícióban, mivel az orvos és a postás nem bizonyult megfelelő személynek a társadalmi csoportok közötti közvetítésben. Összekötố szerepet felvállaló családtagot azonban találhatunk. Az unokák megfelelóek lennének erre a szerepre, de erôsíteni kellene bennük ezt a nagyon fontos közvetítôi szerepelvárást.

A sok erôs kötés, a családon beliili szolidaritás azonban segítséget is jelent: ha egyszer átjutott egy információ a zárt hálózaton és elindított egy kognitív folyamatot, ennek a cselekvésre váltásával már nem lesz probléma. 
Ha arra a kérdésre keressük a választ, hogy a család miért nem képes magával húzni az idôseket az információs társadalomba, erre vonatkozóan az adataink több, a késóbbiekben célzottan vizsgálható hipotézist is elóhoztak. Feltételezhetố, hogy a család társas kapcsolatrendszere szintén zárt, ez pedig már a társadalom sártságát is elöre vetíti. A családon belüli hierarchia nem vagy erôsen korlátozottan teszi csak lehetôvé, hogy az idôsekhez eljusson az innováció. A családon belül nem norma, nem elvárás, hogy az idős hozzátartozó bármilyen szinten aktív legyen.

Összegzésképpen talán megkockáztatható az a megállapítás, hogy Magyarországon az 50 év feletti korosztály még nem indult el a becki értelemben vett individualizálódás (lásd Beck 2003) fájdalmas, de elkerülhetetlen és a lehetôségeket megsokszorozó ösvényén.

\section{Irodalom}

Beck, Ulrich (2003): A kockázat-társadalom: út egy másik modernitásba. Andorka Rudolf Társadalomtudományi Társaság-Századvég Kiadó, Budapest

Fukuyama, Francis (1995): Trust: The Social Virtues and the Creation of Prosperity. New York: Free Press Granovetter, Mark (1991): A gyenge kötések ereje. A hálózatelemzés felülvizsgálata In.: Angelusz Róbert - Tardos Róbert (szerk.): Társadalmak rejtett hálózata. Magyar Közvéleménykutató Intézet. Budapest. 371-391.

Granovetter, Mark: (1983): The strength of weak ties: a network theory revisited. Sociological Theory, Volume 1, 201-233.]

Putnam, Robert (2000): Bowling alone: the collapse and revival of American community. New York: Simon \& Schuster

Szántó Zoltán (2006): Analitikus szemléletmódok a modern társadalomtudományban. Helikon kiadó, Budapest. 